Vol. 6, No. 1, 2021

\title{
EFFICIENCY OF APPLICATION OF THE MICROBIOLOGICAL METHOD OF WASTE WATER TREATMENT TO REMOVE HEXAMETHYLENDIAMINE
}

\author{
Valeriia Lytvynenko, Alina Dychko \\ National Technical University of Ukraine "Igor Sikorsky Kyiv Polytechnic Institute" \\ 37, Peremohu Ave., Kyiv, 03056, Ukraine \\ valeriialytvynenko18@gmail.com
}

https://doi.org/10.23939/ep2021.01.028

Received: 30.11 .2020

(C) Lytvynenko V., Dychko A., 2021

\begin{abstract}
Wastewater contaminated with hexamethylenediamine (HMD), which is discharged into natural reservoirs, causes damage and loss of hydrobionts, worsens the quality of water which becomes unsuitable for use. For wastewater treatment from HMD, the possibility of applying bacterial culturesdestructors which use the HMD as a nutrition source is considered.
\end{abstract}

Key words: wastewater treatment, hexamethylenedipine, filtration, microorganisms.

\section{Introduction}

Hexamethylenediamine (HMD) is widely used in industry for the production of polyamide materials, as well as a substance in the production of epoxy resins. HMD is the organic compound and its solutions absorb carbon dioxide from the air. With organic and inorganic acids, HMD forms salts, such as hexamethylene diaminopirate which is classified in industry as AH salt. HMD is used to obtain valuable polymer products polyamides, nylons. In its interaction with phosgene, hexamethylenediisocyanate is formed, which is widely used for the production of polyurethane rubber, synthetic varnishes, adhesives, synthetic fibers. HMD is moderately toxic, has irritating effects, causes burns and dermatitis of the skin, mucous membranes of the respiratory tract (Povodzhennia..., 2014). At the same time, hexamethylenediamine is a physiologically active, toxic and dangerous substance (hazard class 2), capable of causing burns, eczema dermatitis, diseases of the nervous system and gastrointestinal tract.

It is known that modern technologies for wastewater treatment containing hexamethylenediamine do not have a $100 \%$ degree of treatment. Wastewater contaminated with HMD, discharged into natural reservoirs, causes the death of hydrobionts and aquatic vegetation, therefore the quality of water deteriorates and it becomes unusable (Povodzhennia..., 2014).

The aim of the research is to establish the dependence of the growth of biomass of microorganisms able to absorb HMD on the temperature at which the maximum degree of wastewater treatment from hexamethylenediamine is obtained.

\section{Current state of wastewater treatment from hexametilenediamine}

Traditionally, methods for wastewater treatment include removal of chemicals by filtration, flocculation, activated charcoal, ion-exchange resins, etc. From 1900 to early 1970 s, treatment objectives were concerned with the removal of suspended and floatable material from wastewater, the treatment of biodegradable organics, and the elimination of disease-causing pathogenic microorganisms.

Most wastewater treatment plants rely on conventional biological treatment systems, such as active sludge processes. In combination with different redox conditions (anaerobic and aerobic), these biological processes assure the removal of organic matter and nutrients (Pushkin et al., 2012). Active sludge processes remove most organic wastewater compounds through biological transformation, volatilization and settling of particle-bound compounds. Some organic wastewater compounds are more persistent, requiring longer solids retention times or

For citation: Lytvynenko V., Dychko A., 2020. Efficiency of application of the microbiological method of waste water treatment to remove hexamethylendiamine. Journal Environmental Problems. Vol. 6, No. 1. p. 28-32. DOI: https://doi.org/10.23939/ep2021.01.028 
advanced treatment processes such as reverse osmosis (Gvozdyak, 2003).

The process of wastewater treatment is accomplished by the microorganisms under restorative conditions. This creates favorable conditions for nitrification-denitrification. Both processes occur simultaneously. At the output, the grouping of microorganisms is characterized by the formation of a rich and diverse species composition of protozoa, which is a regulator of the growth of activated sludge. The excess of active sludge has a high degree of mineralization and is, therefore, well dehydrated. It is exported in bags and used as an organic fertilizer (Gvozdyak, 2003; Lema et al., 2017).

The advantage of active sludge use is that when discharging wastewater with such suspended substances, they do not disturb the natural balance of the reservoir, including the trophic systems (rotifers, small worms, sys infusions are excellent feed for fish). The excess of activated sludge is discharged into the aerobic mineralizer where due to the interrelationships of microorganisms the sludge mass is reduced by $2-3$ times (Safonyk et al., 2019). This technology makes it possible to obtain a rich and varied biocenosis, which provides $99 \%$ biological disinfection of silt and runoff (Hvozdiak et al., 2015).

Among the modern applied biological treatment methods, there are technological solutions including conventional activated sludge (CAS) and membrane bioreactors (MBRs). The choice of technology depends on the treatment conditions and the physicochemical properties of the individual compounds. The factors are complex and variable for different wastewater treatment plants, making each plant a unique microbial ecosystem (Hvozdiak, 2012). Bioremediation principle is based on the use of microorganisms and their metabolic substances, including microbial enzymes, synthesized in this process. In this principle the pollutants oxidize into simpler, non-polluting substances and debris, thereby contributing to efficient recycling of wastewater and is most cost-effective (Hvozdiak, 2012). Since the early 1990s, microbial treatment process has gained increasing attention due to its facility and high efficiency compared to conventional techniques. Heterotrophic bacteria play an important role in removing organic matters in the wastewater treatment system. These bacteria work in the clusters as floccula, biofilm or granule. A term that could be a synonym to biological wastewater treatment technology is 'biodegradation' (Hvozdiak et al., 2015).

The pilot plant of liquid, toxic waste firing with gas treatment system is quite effective. The plant is capable of processing 5.1 thousand $\mathrm{m}^{3}$ of waste per year, in the form of an oil emulsion, an aqueous solution of caprolactam and its oligomers (Pushkin et al., 2012). Natural gas is used as the main fuel and fuel oil as additional fuel. The production method is the combustion of water containing HMD. But hightemperature combustion produces a number of combustion products and raises a number of questions and tasks regarding the air environment purification from the chemical spinning shop where these processes take place (Safonyk et al., 2019). Sewage treatment plants and biosolid landfills are considered as potential sources of bioaerosols. Residents living $\sim 200 \mathrm{~m}$ away from a composting plant are exposed to bioaerosols and suffer from irritations (Hvozdiak et al., 2015).

Therefore, the method of high-temperature combustion of liquid wastes containing HMD is inefficient and requires additional costs for the purification of the atmospheric environment of the work premises.

Bacterial culture destructors are used to treat sewage from HMD using HMD as a power source. The basis of the microbiological method is the use of spore bacteria Bacillus subtilis, for which HMD is a source of carbon, nitrogen and energy. In industry, these bacterial cultures are used during microbiological treatment in an installation (Pushkin et al., 2012) which includes a neutralizer, three bioreactors with nozzle "an eyelash" type nozzles, which contain the microorganismsdestructors and a sump. Wastewater contaminated with HMD (concentration $2.5 \mathrm{~g} / \mathrm{dm}^{3}$ ), at the temperature of + $60 \ldots 80{ }^{\circ} \mathrm{C}$ is supplied by pumps from storage tanks of dissolution of $\mathrm{AH}$ salt (salt of adipic acid and HMD) to the neutralizer where for the activity of microorganismsdestructors the necessary parameters are created. For this purpose, the effluents are cooled to $+30^{\circ} \mathrm{C}$, and the $\mathrm{pH}$ is adjusted to 9 with the input of a $10 \%$ solution of orthophosphoric acid (Hvozdiak, 2012).

A feature of another microbiological treatment technology is the supply of the effluent from the pump to the bioreactors where they are sprayed by the nozzles. The biomass of microorganisms-destructors grown under laboratory conditions is introduced into the biomass chamber. In bioreactors, on nanofiber nozzles, the process of absorption and splitting of HMD by microorganisms is carried out (Lema et al., 20170.

Wastewater is aerated for better mixing and for enhanced treatment efficiency in bioreactors. The intensity of water aeration is from 50 to $100 \mathrm{~m}^{3} / \mathrm{h}$. After treatment in bioreactors, the wastewater enters the sump tank, where the biomass precipitates and the effluents cleared from the HMD are sent to the storage pond.

Treatment of sewage from HMD is an actual problem for the enterprise "Chernihiv Khimvolokno" (Ukraine), on the territory of which there is an artificial pond, in which about $1600 \mathrm{~m}^{3}$ of industrial wastewater from the production of polymer "anide" containing HMD 
has been stored for more than 25 years. The concentration of HMD in the wastewater of chemical fiber production reaches very high values, up to $2540 \mathrm{mg} / \mathrm{dm}^{3}$ [Santos et al., 2012]. The gist of treatment biotechnology lies in the employment of the widest range of hydrobionts in the process of sewage treatment, starting with the bacteriadestructors of the most dangerous, toxic synthetic chemical substances (xenobiotics), and ending with high-concentration chemicals [Shatokhina 2013].

\section{Material and Methods}

The efficiency of wastewater treatment using the technology of bacterial destruction is mostly influenced by the concentration of $\mathrm{P}_{2} \mathrm{O}_{5}$ in the wastewater, the active reaction of $\mathrm{pH}$, the airflow rate for aeration, the ratio of the biomass of microorganisms and wastewater, as well as temperature [Sablii 2009].

High and low temperatures have different effects on the conditions of microorganisms growth. High temperatures cause irreversible colloidal changes in plasma, leading to the death of microorganisms.

The optimum $\mathrm{pH}$ level is in the range of 8.5-9, the concentration of $\mathrm{P}_{2} \mathrm{O}_{5}$ is $70-100 \mathrm{mg} / \mathrm{dm}^{3}$ (Awad et al., 2014). The extent of wastewater treatment depends on the airflow rate for aeration. During aeration, water is saturated with air bubbles, then oxygen from the bubbles is absorbed by the water and transferred to the microorganisms. The rate of oxygen consumption by microorganisms increases with the increase of the airflow, reaching the optimum value in the range of 50$100 \mathrm{~m}^{3} / \mathrm{h}$ (Shatokhina, 2013).
The eperimental studies of the effectiveness of microbiological sewage treatment at "Chernihiv Khimvolokno" under different temperature conditions were carried out.

To establish the dependence of the growth of the amount of biomass on the temperature, the mathematical modelling of the process of wastewater treatment from hexamethylenediamine is used. An equation of the Monotype is used to describe the growth of the bacterial population. This method is often used to test the suitability of substances for growing bacteria. Prognostication water quality in reservoirs carried out according to existing mathematical models (for accepted standardized indicators) to a large extent allows determining the required degree of wastewater treatment.

\subsection{Temperature dependence of biomass growth}

It is established that at temperatures from $25^{\circ} \mathrm{C}$ to $32{ }^{\circ} \mathrm{C}$, the amount of biomass increased, and with further increase in temperature, it decreased. Thus, the optimal and maximum values of temperature at which microorganisms were able not only to survive but also to reproduce were determined. The obtained results illustrate that interrelations and correlation dependences were established between the amount of microorganism biomass and the degree of treatment. The given indicators allowed to determine the rational parameters of wastewater treatment from HMD. The temperature dependence of microbial biomass is shown in Fig. 1.

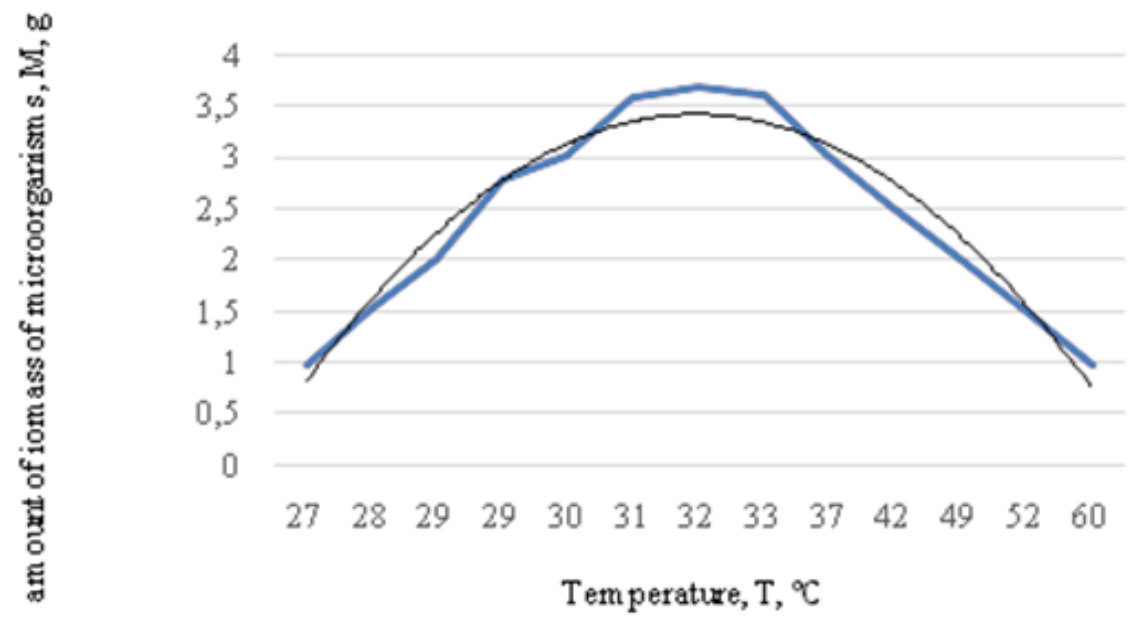

Fig. 1. Dependence of biomass of microorganisms amount $M$ from temperature $T$

The established dependence of the amount of biomass of microorganisms from the temperature of the treatment process is described by a polynomial of the second degree:

$$
\mathrm{M}=-0.0731 \mathrm{~T}^{2}+1.0193 \mathrm{~T}+0.1317
$$

where $\mathrm{M}$ is the mass of microorganisms, $\mathrm{g}, \mathrm{T}$ is the temperature of wastewater, ${ }^{\circ} \mathrm{C}$.

The value of the function changes when the temperature changes from 27 to $60{ }^{\circ} \mathrm{C}$. At the same time 
at a temperature from 27 to $31^{\circ} \mathrm{C}$ there is an increase in the amount of biomass. At temperatures from 31 to $33{ }^{\circ} \mathrm{C}$, the function becomes stable. These are the optimal conditions for microorganisms. As the temperature rises from 33 to $60{ }^{\circ} \mathrm{C}$, the function decreases, so the amount of biomass decreases too.

According to dependence (1), the function acquires a maximum value at $\mathrm{T}=32{ }^{\circ} \mathrm{C}$, and the amount of biomass of microorganisms used for treatment increases parabolically with increasing temperature. Optimal temperature values for biomass growth are $+30 \ldots 34{ }^{\circ} \mathrm{C}$. Therefore, the most effective treatment is achieved at $\mathrm{T}=32{ }^{\circ} \mathrm{C}$ and the optimal amount of biomass that enters the wastewater is $\mathrm{M}=6.9 \mathrm{~g}$.

When adding a source of phosphorus $-\mathrm{P}_{2} \mathrm{O}_{5}$ to the wastewater samples with concentration from 10 to $100 \mathrm{mg} / \mathrm{dm}^{3}$, it was found that an increase in the concentration of $\mathrm{P}_{2} \mathrm{O}_{5}$ in the solution leads to a decrease in the concentration of HMD. The most effective solution for sewage treatment is the $\mathrm{P}_{2} \mathrm{O}_{5}$ solution with a concentration of $70-100 \mathrm{mg} / \mathrm{dm}^{3}$. Fig. 2 shows the content of hexamethylenediamine in the wastewater after treatment and in comparison with the acceptable content.

The results of research on wastewater treatment in the system "enterprise - pond-drive" revealed that, in comparison with the conventional treatment scheme, the proposed microbiological method provides the necessary completeness of removing HMD from wastewater before its discharge into the reservoir. When treating sewage with a solution of HMD in the concentration of 0.0025 $0.03 \mathrm{~g} / \mathrm{dm}^{3}$ by the proposed technology, the biomass concentration does not reach $0.01 \mathrm{~g} / \mathrm{dm}^{3}$. When more than $7 \mathrm{~g}$ of microorganisms is added to the water, the concentration of hexametulenediamine decreases to $0.0005 \mathrm{~g} / \mathrm{dm}^{3}$.

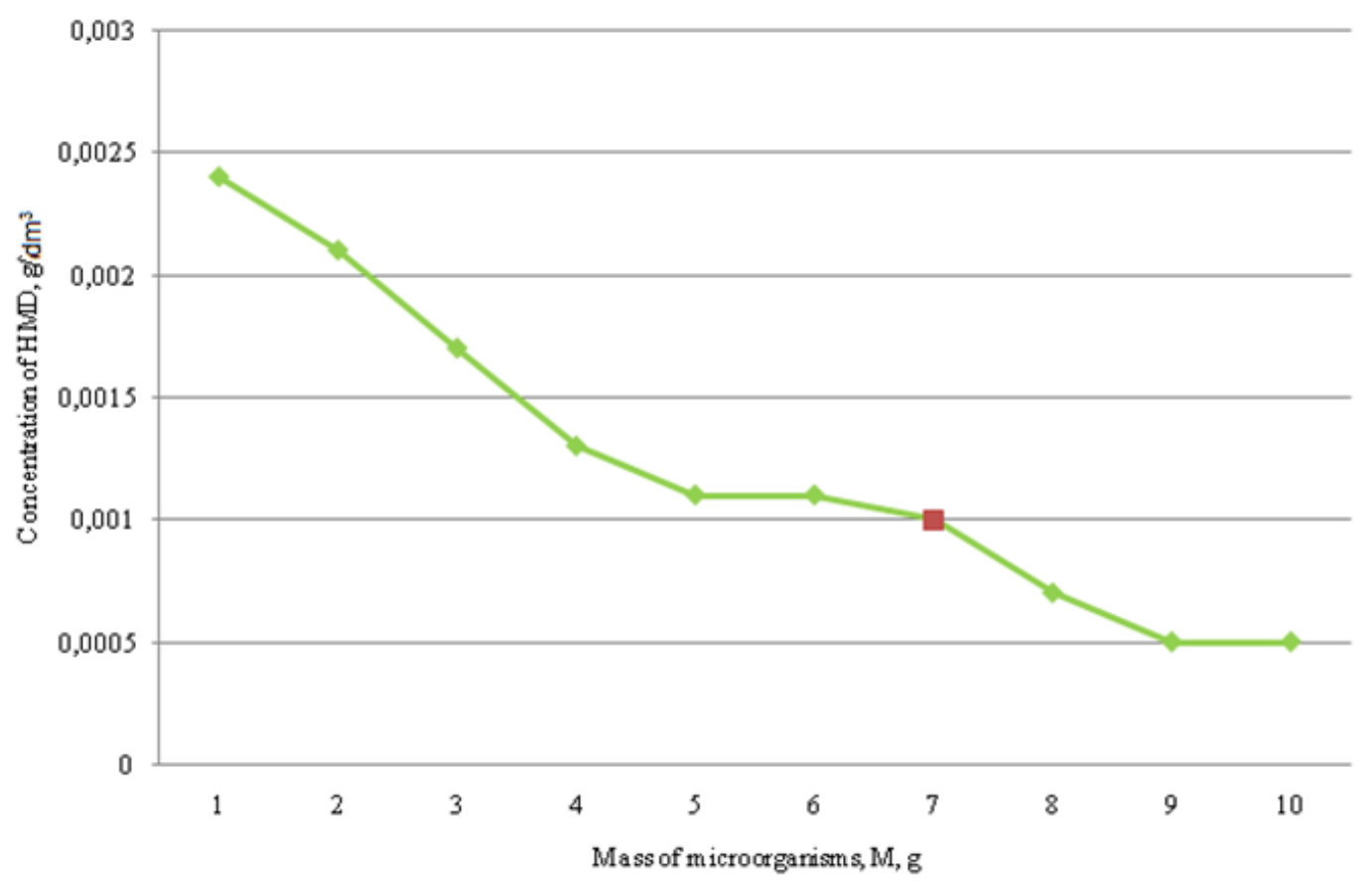

Fig. 2. Hexamethylenediamine content in wastewater after treatment

An important issue that arises from the application of the microbiological method is the excess of the biomass of microorganisms that is generated and leached from the bioreactors and cannot completely settle in the secondary sump due to the very small size of the bacteriadestructors. This problem can be solved by using a bioconveyor [Sablii 2009]. The technological essence of the "bioconveyor" is that hydrobionts - anaerobic bacteria, aerobic microorganisms, and filters are placed on the path of wastewater to be purified. They consume water-soluble organic compounds and the biomass of lower-trophic organisms. The more trophic levels get involved in the bioreactor, the less biomass remains in the purified water.

The use of a microbiological treatment method is efficient in the treatment of the effluents of hexamethylenediamine, and the technology of "bioconveyor" allows the processing of excessive biomass of microorganisms, which is leached from the bioreactors. The treatment process is easy to manage, and it can be completely automated. The minimal parameters required are the availability of aerobic bioreactors, temperature, $\mathrm{pH}$ and the concentration of $\mathrm{P}_{2} \mathrm{O}_{5}$. To treat wastewater from HMD, the possibility of using bacterial 
cultures-destructors that consume HMD as a nutrient source is considered. The microbiological method is based on highly effective spore bacteria Bacillus subtilis with the use of the additional source of phosphorus.

\section{Conclusions}

The dependence of the amount of biomass of microorganisms entering the wastewater on the wastewater temperature $\mathrm{M}=-0.0731 \mathrm{~T}^{2}+1.0193 \mathrm{~T}+0.1317$ is determined. The established dependence allows predicting the necessary amount of biomass which needs to be used in the sewage treatment system to reach the maximum degree of treatment.

It was found that the wastewater treatment with the HMD concentration of $0.0025 \mathrm{~g} / \mathrm{dm}^{3}$ by the proposed technology leads to residual concentration of $0.0005 \mathrm{~g} / \mathrm{dm}^{3}$, i.e. the efficiency of wastewater treatment from HMD allows reducing the HMD concentration which is twice less than the maximum acceptable level.

\section{References}

Awad, A. H., \& el Gendy, S. A. (2014). Evaluation of airborne Actinomycetes at waste application facilities. Atmospheric Pollution Research, 5(1), 1-7. doi: https://doi.org/10.5094/ APR.2014.001

Gvozdyak, P. I. (2003). Za pryntsypom biokonveiera. Biotekhnolohiia okhorony dovkillia. Visnyk NAN Ukrainy. (pp. 29-36), March, 2003. Kyiv: NAN Ukrainy. [in Ukraine]

Hvozdiak, P. I., Sapura, O. V. \& Chekhivska, T. P. (2015). Biotekhnolohichne zneshkodzhennia heksametylendiaminvmisnykh promyslovykh toksychnykh vidkhodiv u stavku-nakopychuvachi. Visnyk Natsionalnoho universytetu vodnoho hospodarstva ta pryrodokorystuvannia, 1 (69), 102-110. [in Ukraine]

Hvozdiak, P. I. (2012). Biokhimiia vody yak naukove pidgruntia biotekhnolohii vody. Ekolohichna ta tekhnohenna bezpeka. Okhorona vodnoho ta povitrianoho baseiniv. Utylizatsiia vidkhodiv, (12), 8-14. [in Ukraine]

Lema, J.M., \& Suarez, S. (2017). Innovative Wastewater Treatment \& Resource Recovery Technologies: Impacts on Energy, Economy and Environment. March, 2017. London, UK,IWA Publishing

Povodzhennia $\mathrm{z}$ nebezpechnymy vidkhodamy na pidpryiemstvi. (2014). Bushfire resources: Ecobusiness Group. Retrieved from http://ecolog-ua.com/content/povodzhennya-znebezpechnimi-vidhodami-na-pidpriiemstvi [in Ukraine]

Pushkin, S. P. \& Shapoval, Yu. A. (2012). Metody ochyshchennia stichnykh vod vid heksametylendiaminu $\mathrm{z}$ metoiu zabezpechennia bezpeky pratsi. Informatsiinyi biuleten z okhorony pratsi. Kyiv, Ukraina: NNDIPBOP. [in Ukraine]

Sablii, L. A. (2009). Bahatostupeneva anaerobno-aerobne ochyshchennia vysokokontsentrovanykh stichnykh vod. Visnyk Natsionalnoho universytetu vodnoho hospodarstva ta pryrodokorystuvannia, (117), 19-22. [in Ukraine]

Safonyk, A. P., \& Tarhoniy, I. M. (2019). Computer simulation of aerobic sewage treatment. Journal of Mechanical Engineering, 41 (5), 31-36. doi: https://doi.org/10.15407/ emodel.41.05.017

Santos, A. F., Santos, C. P., Matos, A. M., Cardoso, O., \& Quina, M. J.(2012). Effect of Thermal Drying and Chemical Treatments with Wastes on Microbiological Contamination Indicators in Sewage Sludge. Microorganisms, 13 (157), 376-378. doi: https://doi.org/10.3390/microorganisms 8030376

Shatokhina, Yu. V. (2013). Potentsiini nebezpeky u vodopostachanni ta vodovidvedenni. Visnyk Kyivskoho natsionalnoho universytetu tekhnolohii ta dyzainu, (2), 140-143. [in Ukraine] 